
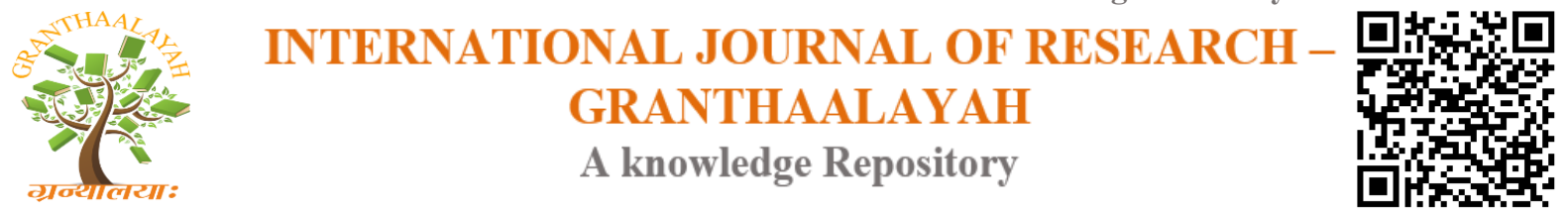

Management

\title{
MEASURING CUSTOMERS' ATTITUDE TOWARDS INNOVATIVE BANKING SERVICES OF PUBLIC AND PRIVATE SECTOR IN TIRUNELVELI DISTRICT
}

\author{
Bulomine Regi. S ${ }^{1}$, Dr.C. Eugine Franco ${ }^{2}$ \\ ${ }^{1}$ Ph.D Research Scholar Full Time in Commerce, St. Xavier's College (Autonomous), \\ Palayamkottai, INDIA \\ ${ }^{2}$ HOD of Commerce, St. Xavier's College (Autonomous), Palayamkottai, INDIA
}

\begin{abstract}
The beginning of empowerment of banking customers for their own transactions started with the evolution of ATMs as a delivery channel. The emergence of innovative banking services such as Self Service Banking Technologies (SSBT) i.e ATMs/ Debit Card, Credit Card, Internet Banking (IB), Mobile Banking (MB) with the concept of "Anytime and Anywhere Banking" has intensified the need of innovative banking services. With the advent of internet, the application of innovative banking services has been proven as an effective way to reduce the costs of operation for the financial institutions. Innovative banking services do allow banks to reduce expenditures on physical structures. It is believed that the e-banking will help the banks to cut costs, increase revenue and become more convenient for customers to do banking transactions. The methodology used in the study four banks were selected for the study and 90 customers were selected from each bank purposively those who are using innovative banking services namely ATM/Debit Card, Credit Card, Internet Banking and Mobile Banking. Four banks were selected based on Technological Award 2013-14. The select banks are State Bank of India, Canara Bank of public sector and ICICI and AXIS of private sector banks. The interview schedule was categorised into six parts using TAM extension model framed by the researcher. So it is important to anlayse the customers' attitude towards innovative banking services of public and private sector banks.
\end{abstract}

Keywords:

Customers' attitude, Technology Acceptance Model (TAM), ATM/Debit Card, Credit Card, Internet Banking, Mobile Banking, Innovative Banking Services.

Cite This Article: Bulomine Regi. S, and Dr.C. Eugine Franco, "MEASURING CUSTOMERS' ATTITUDE TOWARDS INNOVATIVE BANKING SERVICES OF PUBLIC AND PRIVATE SECTOR IN TIRUNELVELI DISTRICT" International Journal of Research - Granthaalayah, Vol. 4, No. 5: SE (2016): 58-66. 


\section{INTRODUCTION}

The beginning of empowerment of banking customers for their own transactions started with the evolution of ATMs as a delivery channel. The emergence of innovative banking services such as Self Service Banking Technologies (SSBT) i.e ATMs/ Debit Card, Credit Card, Internet Banking (IB), Mobile Banking (MB) with the concept of "Anytime and Anywhere Banking" has intensified the need of innovative banking services. With the advent of internet, the application of innovative banking services has been proven as an effective way to reduce the costs of operation for the financial institutions. Innovative banking services do allow banks to reduce expenditures on physical structures. It is believed that the e-banking will help the banks to cut costs, increase revenue and become more convenient for customers to do banking transactions. The internet is more than a physical platform for banking transactions; it is a medium for communicating and interacting with customers more effectively and efficiently. It can be utilised as a niche instrument and a medium for highly customised contacts with existing and potential customers. It also helps to developed over time using information collected through transactions with customers. This leads to customisation/personalisation to maintain good relationship with the customers by immediately responding them through online without delay which gives good enough to maintain electronic customer relationship management (e-CRM) in banking industry. The attractiveness towards internet into internet banking which enhanced by the ability to conduct banking transactions anytime and anywhere, faster and with lower charges compared to using traditional bank branches.

\section{OBJECTIVES OF THE STUDY}

- The following are the objectives of the present study:

- To study the socio-economic condition of the respondents in the study area.

- To measure the customers' attitude towards innovative banking services offered by public and private sector banks in Tirunelveli District.

\section{METHODOLOGY}

Four banks were selected for the study and 90 customers were selected from each bank purposively those who are using innovative banking services namely ATM/Debit Card, Credit Card, Internet Banking and Mobile Banking. Four banks were selected based on Technological Award 2013-14. The select banks are State Bank of India, Canara Bank of public sector and ICICI and AXIS of private sector banks. The interview schedule was categorised into six parts using TAM extension model framed by the researcher.

\section{Proposed Research Model using TAM}

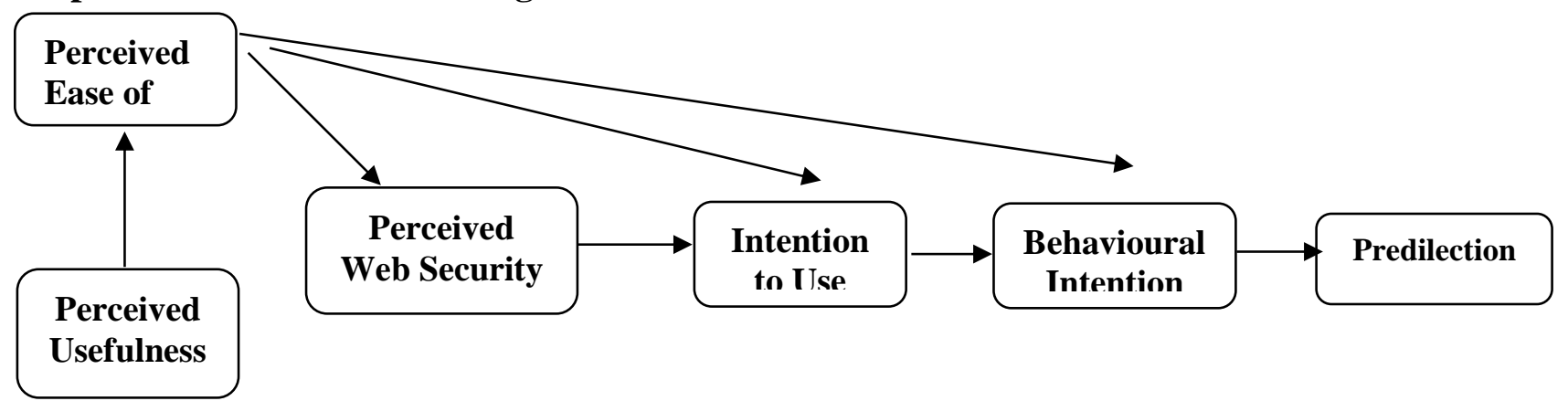




\section{FINDINGS AND DISCUSSION}

The attitude is measured to find out the positive and negative feelings and beliefs of the customers towards innovative banking services. The customers' attitude towards innovative banking services was tested using extended TAM model framed by the researcher using perceived usefulness, perceived ease of use, perceived web security, intention to use, behavioural intention and predilection

The following tables describe the customers' attitude towards innovative banking services.

\section{Measuring Customers' Attitude Using Perceived Ease of Use}

The perceived ease of use is analysed to measure the attitude of the customers using innovative banking services to identify an individual believes that a particular system would be based on physical and mental effort. The following table examines the attitude of customers using innovative banking services based on their perceived ease of use.

Table 1: Mean Rank on Measuring Customers' Attitude Using Perceived Ease of Use

\begin{tabular}{|l|l|l|l|}
\hline \multirow{2}{*}{ PERCEIVED EASE OF USE } & Sector of Bank & \multirow{2}{*}{ Total } \\
\cline { 2 - 3 } & Public & Private & \\
\hline $\begin{array}{l}\text { Using the Innovative Banking services are easy } \\
\text { for me }\end{array}$ & 3.68 & 3.81 & 3.74 \\
\hline $\begin{array}{l}\text { Learning to operate the innovative banking } \\
\text { services are easy for me (Self-Learning) }\end{array}$ & 3.42 & 3.19 & 3.31 \\
\hline $\begin{array}{l}\text { Interacting with technology for using innovative } \\
\text { banking services are often frustrating } \\
\text { (Disappointment) }\end{array}$ & 2.48 & 3.92 & 3.20 \\
\hline $\begin{array}{l}\text { I find it easy to get the innovative banking } \\
\text { services to do what I want it to do }\end{array}$ & 3.34 & 3.79 & 3.57 \\
\hline $\begin{array}{l}\text { It is easy to remember how to perform tasks and } \\
\text { takes a lot of effort to become skilful for using } \\
\text { innovative banking services }\end{array}$ & 3.70 & 4.06 & 3.88 \\
\hline $\begin{array}{l}\text { Interacting with the technological devices need a } \\
\text { lot of mental effort }\end{array}$ & 2.88 & 3.11 & 2.99 \\
\hline $\begin{array}{l}\text { My interaction with the technological devices } \\
\text { are clear and understandable }\end{array}$ & 2.94 & 3.73 & 3.34 \\
\hline $\begin{array}{l}\text { I would find it easy to get information about } \\
\text { latest banking services }\end{array}$ & 3.12 & 4.49 & 3.81 \\
\hline It is very easy to get my account statement & 2.62 & 3.64 & 3.13 \\
\hline $\begin{array}{l}\text { I seek advice from my family members } \\
\text { friends/bank employees/ colleagues before I use } \\
\text { innovative banking services }\end{array}$ & 2.28 & 3.44 & 2.86 \\
\hline $\begin{array}{l}\text { Overall, I find the Innovative Banking services } \\
\text { are easy to use }\end{array}$ & 3.22 & 2.86 & 3.04 \\
\hline
\end{tabular}

Source: Primary Data 
Based on the mean score, the public sector customers felt that is easy to remember the tasks to be performed and need little more effort to become skillful to use innovative banking services and customers are favouable that using selected innovative banking services is easy whereas the private sector customers felt the innovative banking services help to get information about banking services easily and it is easy to access innovative banking services.

Inference: It is inferred that, both public and private sector customers are felt that using innovative banking services helps to reduce their physical and mental effort to avail banking services easily.

\section{Measuring Customers' Attitude Using Perceived Usefulness}

The perceived usefulness is used to analyse the individual believes in enhancing themselves in the usage of innovative banking services. The following table examines the attitude of customers using innovative banking services based on their perceived usefulness:

Table 2: Mean Rank on Measuring Customers' Attitude Using Perceived Usefulness

\begin{tabular}{|l|l|l|l|}
\hline \multirow{2}{*}{ PERCEIVED USEFULNESS } & \multicolumn{2}{|l|}{ Sector of Bank } & \multirow{2}{*}{ Total } \\
\cline { 2 - 3 } & Public & Private & \\
\hline $\begin{array}{l}\text { Innovative Banking Services enable me to accomplish } \\
\text { my tasks more quickly }\end{array}$ & 3.43 & 4.08 & 3.76 \\
\hline It gives me greater control over my transaction & 3.46 & 4.01 & 3.73 \\
\hline $\begin{array}{l}\text { It supports critical aspects of my dealing with banking } \\
\text { services }\end{array}$ & 3.56 & 4.42 & 3.99 \\
\hline It improves my banking activities & 3.73 & 4.34 & 4.04 \\
\hline $\begin{array}{l}\text { It allows me to accomplish more transaction through } \\
\text { technological based innovative banking services than } \\
\text { using currency notes }\end{array}$ & 3.89 & 4.03 & 3.96 \\
\hline $\begin{array}{l}\text { It would be difficult to perform banking activities } \\
\text { without IBS }\end{array}$ & 3.66 & 4.30 & 3.98 \\
\hline $\begin{array}{l}\text { I feel technology helps me fulfil my timely need of } \\
\text { banking services }\end{array}$ & 3.39 & 4.14 & 3.77 \\
\hline $\begin{array}{l}\text { Overall, I would find using the Innovative Banking to be } \\
\text { advantageous }\end{array}$ & 3.90 & 3.71 & 3.80 \\
\hline
\end{tabular}

Source: Primary Data

Based on the mean score, the public sector customers felt that overall using innovative banking services are advantageous, innovative banking services accomplish more transactions through technological banking rather than currency notes and it helps to improve the banking activities of the customers whereas the private sector customers felt that using innovative banking services supports in dealing with banking services at critical aspects without rushing to banks during working hours, it helps to improve the banking activities of the customers and the customers are felt positive that it is difficult to perform banking activities without innovative banking services.

Inference: It is inferred that, both public and private sector customers enhance themselves easily in adopting and using innovative banking services. 


\section{Measuring Customers' Attitude Using Perceived Web Security}

The perceived web security is used to analyse the security measures followed by the customers to use safe and secure IBS for banking transactions. The following table examines the attitude of customers using innovative banking services based on the web security:

Table 3: Mean Rank on Measuring Customers' Attitude Using Perceived Web Security

\begin{tabular}{|l|l|l|l|}
\hline \multirow{2}{*}{ PERCEIVED WEB SECURITY } & \multicolumn{2}{l|}{ Sector of Bank } & \multirow{2}{*}{ Total } \\
\cline { 2 - 3 } & Public & Private & \\
\hline $\begin{array}{l}\text { I use IBS using the website address received } \\
\text { through e-mails }\end{array}$ & 2.93 & 3.88 & 3.41 \\
\hline $\begin{array}{l}\text { I access internet banking by copy-pasting the } \\
\text { website address of bank from other websites }\end{array}$ & 3.35 & 3.97 & 3.66 \\
\hline I don't open e-mails whose origin is unknown & 3.12 & 2.44 & 2.78 \\
\hline I change my password frequently & 2.71 & 2.74 & 2.73 \\
\hline I don't disclose my password to anyone & 3.47 & 4.07 & 3.77 \\
\hline $\begin{array}{l}\text { I use same password/PIN for all the banks where } \\
\text { I'm accessing IBS }\end{array}$ & 2.39 & 3.54 & 2.96 \\
\hline $\begin{array}{l}\text { I write my user ID and Password/PIN in a diary, } \\
\text { card cover, draft in mobile/ e-mail etc. }\end{array}$ & 2.37 & 4.03 & 3.20 \\
\hline $\begin{array}{l}\text { I don't reply to emails that ask for my user ID and } \\
\text { password }\end{array}$ & 3.27 & 3.27 & 3.27 \\
\hline $\begin{array}{l}\text { I access IBS from networked computers (cyber } \\
\text { cafe) }\end{array}$ & 2.14 & 3.23 & 2.68 \\
\hline I log off/log out the services immediately after use & 4.46 & 3.73 & 4.10 \\
\hline $\begin{array}{l}\text { I read the tips for safe use of IBS on the bank } \\
\text { website clearly and frequently }\end{array}$ & 3.57 & 3.76 & 3.66 \\
\hline $\begin{array}{l}\text { I verify the last date and time log off given in the } \\
\text { IBS }\end{array}$ & 3.39 & 3.55 & 3.47 \\
\hline Fear about hackers & 3.00 & 3.88 & 3.44 \\
\hline $\begin{array}{l}\text { Authentication and session management increases } \\
\text { secure and safety }\end{array}$ & 3.44 & 3.27 & 3.36 \\
\hline I verify all my IBS transactions periodically & 4.26 & 3.18 & 3.72 \\
\hline I feel it's fully secured to make transaction & 4.43 & 3.71 & 4.07 \\
\hline $\begin{array}{l}\text { Overall, the Innovative Banking is a safe place to } \\
\text { transmit sensitive information }\end{array}$ & 3.93 & 3.66 & 3.79 \\
\hline
\end{tabular}

Source: Primary Data

Based on the mean score, the public sector customers are log off/log out the services immediately after using innovative banking services, periodically verifying their innovative banking services transactions and felt fully secured to make transactions using innovative banking services whereas in the case of private sector, customers are not disclosing their password to anyone and change their password/PIN number frequently but they have the practice of writing user id, password/PIN in the diary. It is observed that, due to frequent change of password leads to confusion in using password/PIN or intends to forget the password/PIN. So the customers are having the practice of note down the password/PIN in note books. 
Inference: It is inferred that, both public and private sector customers using innovative banking services are conscious about the security issues while availing innovative banking services like ATM/Debit Card, Credit Card, Internet Banking and Mobile Banking but still need to improve themselves in many aspects to protect their account from hackers.

\section{Measuring Customers' Attitude Using Intention to Use}

The intention to use is applied to measure customers' intention in using innovative banking services. The following table examines the attitude of customers using innovative banking services based on their intention to use:

Table 4: Mean Rank on Measuring Customers' Attitude Using Intention to Use

\begin{tabular}{|l|l|l|l|}
\hline INTENTION TO USE & \multicolumn{2}{|l|}{ Sector of Bank } & \multirow{2}{*}{ Total } \\
\cline { 2 - 3 } & Public & Private & \\
\hline $\begin{array}{l}\text { I can do myself using the technology based } \\
\text { Innovative Banking Services for handling my } \\
\text { banking transactions }\end{array}$ & 4.16 & 3.58 & 3.87 \\
\hline It is very less time consuming & 4.22 & 3.06 & 3.64 \\
\hline I can use it successfully every time & 3.57 & 4.01 & 3.79 \\
\hline It gives flexible time to use the banking services & 3.18 & 3.63 & 3.40 \\
\hline $\begin{array}{l}\text { I intend to continue using the innovative banking } \\
\text { services }\end{array}$ & 3.94 & 3.31 & 3.63 \\
\hline $\begin{array}{l}\text { I intend to use innovative banking services because } \\
\text { it is user-friendly }\end{array}$ & 4.19 & 3.66 & 3.93 \\
\hline $\begin{array}{l}\text { It is more prestigious than queuing in bank } \\
\text { premises for long hours }\end{array}$ & 4.53 & 3.19 & 3.86 \\
\hline Overall, the Innovative Banking is a safe to use & 4.24 & 3.49 & 3.87 \\
\hline
\end{tabular}

Source: Primary Data

Based on the mean score, both public and private sector customers are having similar intention towards using innovative banking services that is customers are intend to use innovative banking services because it increases the prestigious than queuing in bank premises for long hours, using innovative banking services is less time consuming and can access at flexible time in doing banking transaction.

Inference: It is inferred that, both public and private sector customers using innovative banking services are more time conscious. It is observed that, the branch banking working hours are not suitable to the customers because majority of the customers are working. So, this increase the intention of the customers to use innovative banks services. Measuring Customers' Attitude

\section{Using Behavioural Intention}

The behavioural intention is used to analyse perform or not perform the specified future behaviour. The following table examines the attitude of customers using innovative banking services based on their behavioural intention: 
Table 5: Mean Rank on Measuring Customers' Attitude Using Behavioural Intention

\begin{tabular}{|l|l|l|l|}
\hline \multirow{2}{*}{ BEHAVIOURAL INTENTION } & \multicolumn{2}{|l|}{ Sector of Bank } & \multirow{2}{*}{ Total } \\
\cline { 2 - 3 } & Public & Private & \\
\hline I am very loyal to my bank & 4.39 & 4.23 & 4.31 \\
\hline $\begin{array}{l}\text { My present bank would be my first choice if I need } \\
\text { banking services }\end{array}$ & 4.21 & 3.63 & 3.92 \\
\hline The relationship with bank is important to me & 4.26 & 4.41 & 4.33 \\
\hline $\begin{array}{l}\text { I would encourage my friends and relatives to do } \\
\text { transactions using technology based innovative } \\
\text { banking services }\end{array}$ & 4.36 & 3.88 & 4.12 \\
\hline I will recommend my bank best bank in the area & 4.12 & 3.86 & 3.99 \\
\hline $\begin{array}{l}\text { Technology development in banks lead to unhealthy } \\
\text { relationship with the banker }\end{array}$ & 2.35 & 4.47 & 3.41 \\
\hline Digitalisation of banking services is needed & 3.94 & 3.64 & 3.79 \\
\hline Overall, I recommend the innovative banking services & 4.02 & 2.22 & 3.12 \\
\hline
\end{tabular}

Source: Primary Data

Based on the mean score, the public sector customers are encouraging their friends and relatives to do transactions using technology based innovative banking services; digitalisation of banking services is needed and loyal to their bank whereas the private sector customers felt digitalisation of banking services is needed, encouraging their friends and relatives to do transactions using technology based innovative banking services and the relationship with bank is too important to the customers.

Inference: It is inferred that, both public and private sector customers opined that digitalisation of banking services is needed. It shows that both public and private sector customers are having positive behavioural intention towards innovative banking services. Measuring Customers'

\section{Attitude Using Predilection}

The predilection is used to analyse the individual's positive or negative feeling about performing the target behavior towards innovative banking services. The following table examines the attitude of customers using innovative banking services based on predilection:

Table 6: Mean Rank on Measuring Customers' Attitude Using Predilection

\begin{tabular}{|l|l|l|l|}
\hline \multirow{2}{*}{ PREDILECTION } & \multicolumn{2}{|l|}{ Sector of Bank } & \multirow{2}{*}{ Total } \\
\cline { 2 - 3 } & Public & Private & \\
\hline Using Innovative Banking Services is a good idea & 4.35 & 4.39 & 4.37 \\
\hline $\begin{array}{l}\text { I would feel that using Innovative Banking Services is } \\
\text { pleasant }\end{array}$ & 4.02 & 4.18 & 4.10 \\
\hline $\begin{array}{l}\text { In my opinion, it would be desirable to use Innovative } \\
\text { Banking Services }\end{array}$ & 4.24 & 4.32 & 4.28 \\
\hline I feel unrisky to use the Innovative Banking Services & 4.05 & 4.19 & 4.12 \\
\hline I carefully follow steps to use the services & 4.13 & 3.98 & 4.06 \\
\hline I prefer to use innovative banking services & 4.23 & 3.91 & 4.07 \\
\hline I'm intend to use both traditional and innovative & 2.41 & 2.82 & 2.61 \\
\hline
\end{tabular}




\begin{tabular}{|l|l|l|l|}
\hline banking services & & & \\
\hline $\begin{array}{l}\text { I feel tension free attitude in using innovative banking } \\
\text { services }\end{array}$ & 4.08 & 2.58 & 3.33 \\
\hline $\begin{array}{l}\text { I can able to deal with paperless transaction including } \\
\text { paper currency in future }\end{array}$ & 3.89 & 2.89 & 3.39 \\
\hline $\begin{array}{l}\text { I felt happy that I'm avoid using papers for my } \\
\text { transactions }\end{array}$ & 4.06 & 3.54 & 3.80 \\
\hline I need banking services not banks & 3.97 & 3.73 & 3.85 \\
\hline $\begin{array}{l}\text { In my view, using Innovative Banking Services are } \\
\text { safe and secure }\end{array}$ & 3.54 & 3.77 & 3.66 \\
\hline
\end{tabular}

Source: Primary Data

Based on the mean score, both public and private sector customers prefer to use innovative banking services, felt using innovative banking services are safe and secure and carefully follow steps to use the services and perform the tasks to complete their transactions.

Inference: It is inferred that, customers of both public and private sector banks are feeling positive to avail innovative banking services.

\section{CONCLUSION}

Banking sector plays a vital role in the growth of economic development in India. Banking is still under evolutionary stage as it is adopting new technologies to facilitate further the customer convenience in the secured environment. IBS is becoming popular amongst customers who are familiar with the technology up graduation but it is gradually spreading to mass especially at metropolitan and urban cities. Few banks have taken an early lead by introducing technology based banking services. The study on the customers' attitude towards innovative banking services (IBS) in banking sector reveals that customers are satisfied in some aspects and they want to continue with their respective banks. The shift from cutomerised service to personalized services is highly essential to satisfy all groups of customers. The findings of the study stress upon the importance of the security and safety expected by the customers especially in the case of innovative banking services (IBS) like ATM/Debit Card, Credit Card, Internet Banking, Mobile Banking etc.,. The future of internet banking lies in offering personalized internet based services that are not only valued by their customers but are also unique to them. This would help distinguish themselves in the crowd. This would also help them evolve continuously to meet customers' needs, capitalizing on new technology to build stronger customer relationship.

\section{REFERENCES}

[1] Aijimon Geroge and Gireesh Kumar (2013) TAM Constructs and Extent of Use of Internet Banking: An Empirical Analysis, Commerce Spectrum Double Blind Peer Reviewed Half Yearly Journal ISSN 2321 - 371X, Vol. 1, No. 1, June 2013, pp 18-25 http://www.stpeterscollege.ac.in/publication/Commerce-spectrum-June\%202013.pdf retrieved on 14-01-2016 
[2] Baten and Kamil (2010), E-Banking of Economical Prospects in Bangladesh "Journal of Internet Banking and Commerce, Vol. 15, No.2,http://www.arraydev.com/ commercel JIBC/2010-08/Baten.pdf.

[3] Divya, A., \& Regi, B. An Empirical Study on Effectiveness of Social Media as a Marketing Tool.

[4] Dr. C. Eugine Franco, and Bulomine Regi. S, "ADVANTAGES AND CHALLENGES OF E-COMMERCE CUSTOMERS AND BUSINESSES: IN INDIAN PERSPECTIVE” International Journal of Research - Granthaalayah, Vol. 4, No. 3: SE (2016): 7

[5] Golden, S. A. R. (2015). Regional Imbalance affecting quality of e-banking services with special reference to Tuticorin District-An Analysis. International Journal of Research, 2(3), 788-798.

[6] Golden, S. A. R., \& Regi, S. B. (2015). Satisfaction of Customers towards User Friendly Technological Services offered by Public and Private Sector banks at Palayamkottai, Tirunelveli District. International Journal of Research, 2(3), 775-787.

[7] Muhammed S. Alnsour and Khalil Al-Hyari (2011). Internet Banking and Jordanian Corporate Customers: Issues of Security and Trust, Journal of Internet Banking and Commerce, April 2011, vol. 16, no.1, http://www. arraydev.com /commerce/JIBC/201104/Alnsour.pdf.

[8] Regi, S. B. \& S, A. R. G. (2014). “A DESCRIPTIVE STUDY ON THE ROLE OF CONSUMER PSYCHOLOGY AND BEHAVIOUR IN PRODUCT PURCHASING”. Indian Streams Research Journal, 3.

[9] Sayar, C and Wolfe, S. (2007). Internet banking market performance: Turkey versus the UK. International Journal of Bank Marketing, Vol: 25, No.3, pp 122-141. 